Prace Literackie LVIII

Wrocław 2018

https://doi.org/10.19195/0079-4767.58.14

TOMASZ CHOMISZCZAK

ORCID: 0000-0002-2322-319X

Uniwersytet Pedagogiczny im. KEN w Krakowie

\title{
Pisarz „stąd”, „stamtąd” i „,spomiędzy”. Mariana Pankowskiego z kulturą narodową przypadki
}

Marian Pankowski był jednym ze szczególnych przypadków w literaturze polskiej: oto dawny mieszkaniec podkarpackiego pogranicza kultur i języków osiadł po drugiej wojnie światowej w Belgii, lecz stał się emigrantem nietypowym, skoro publikował jednocześnie w ośrodkach zachodnioeuropejskich i w Polsce. Dla krajowych krytyków, zwłaszcza w PRL, pozostawał wciąż pisarzem „stamtąd”. A przecież Pankowskiemu ideologicznie nie po drodze było i z londyńskimi „Wiadomościami”, i z paryską „Kulturą” — z obydwoma ośrodkami zerwał współpracę po paru latach, podkreślając tym samym własną niezależność światopoglądową i artystyczną. Autor Smagłej swobody wyznawał zresztą, że od dziecka stronił „od postaw wspólnych, tłumnych, gremialnych”, zawsze szukając „miejsca samotnego czy stroju indywidualnego"1. Ta cecha charakterologiczna była jednym z elementów decydujących o jego życiowo-zawodowym wyborze właśnie Brukseli, oddalonej od wielkich ośrodków kulturalnych, także tych polskoemigranckich. Wyborze, dodajmy, dość ryzykownym, gdyż Pankowski, odcinając się od ówczesnego dyktatu literackiego Paryża, przyznawał, iż pod względem artystycznym Bruksela była w tamtym czasie — pospołu z Rzymem, Londynem, Sztokholmem, a nawet Nowym Jorkiem — ,prowincjonalną agencją”, ledwie ,jednym z kulturalnych przedmieść Paryża”"2. Tym bardziej widział jednak, wzorem swojego literackiego mistrza Michela de Ghelderode'a, palącą potrzebę „opierania się łatwym urokom Paryża”3.

${ }^{1}$ Polak $w$ dwuznacznych sytuacjach. Z Marianem Pankowskim rozmawia Krystyna Ruta-Rutkowska, Warszawa 2000, s. 110.

2 M. Pankowski, Michel de Ghelderode, „Kultura” 1956, nr 11, s. 51.

3 Ibidem, s. 52. Ghelderode'owi, którego kilka utworów literackich przetłumaczył na polski, Pankowski spłacał swój dług wdzięczności przez całe życie, przy każdej okazji w superlatywach 
Sytuacja „rozdwojenia” czy też „rozszczepienia” stanie się znakiem rozpoznawczym Pankowskiego ${ }^{4}$. Podkreślający na każdym kroku polskość, a ściślej — „karpackość”, polski pisarz dość szybko asymiluje się w swojej drugiej ojczyźnie: w Brukseli zakłada rodzinę i rozpoczyna pracę na Université Libre, gdzie pokona kolejne szczeble kariery akademickiej. Współpracuje jednocześnie przy organizacji Biennale Poetyckiego w Knokke, pisze i tłumaczy do pisma „Journal des Poètes", wygłasza odczyty, słowem — jest czynnym i twórczym uczestnikiem belgijskiego środowiska artystyczno-kulturalnego. W oficjalnych wypowiedziach, tekstach pisanych i wywiadach Pankowski nie omieszkał wielokrotnie wychwalać „odkrywanego” przezeń kraju i jego tradycji. „Pokochałem Belgię od chwili, gdy tu przybyłem. Odpowiada mojemu wrodzonemu zamiłowaniu do nadmiaru, mojemu upodobaniu do transgresji”, mówił jednemu z dziennikarzy ${ }^{5}$; w rozmowie zaś z innym swój powieściowy debiut komentował następująco: „Sądzę, że moja pierwsza powieść, Matuga idzie, ujawnia [...] moje przystąpienie do tej aury umysłowej, że tak powiem, Breughlowskiej"'.

A jednak, wzorem Jana, bohatera swojej powieści Gość, Pankowski w nowej ojczyźnie wydaje się nieustannie uciekać przed sformalizowaniem, nie chce dać się ując w jakiekolwiek ramki. Jego żywiołem jest nieustanne wymykanie się: nie tylko czytelnikom i krytykom, lecz także powszechnie przyjętym sposobom określania narodowej oraz literackiej tożsamości. Obwieszczał to już w słynnym programowym wstępie do powieści Matuga idzie, pisząc: „Jestem węgorz uciekający z oschłego Nieba Praw rządzonych Prawami. Jestem uciekinier od Panprawidłowości"”. Szedł tym samym w ślady Witolda Gombrowicza, który napominał w swoim Dzienniku: „Bądź zawsze obcy! [...] Nie daj się swoim oswoić, przyswoić! Twoje miejsce nie jest wśród nich, ale poza nimi, jesteś jak sznur, zwany przez dzieci skakanką — wyrzuca się go przed siebie, aby przeskoczyć" 8 .

Skojarzenie sytuacji Pankowskiego z Gombrowiczem wydaje się ze wszech miar zasadne. Obaj — oczywiście należy zachować tu wszelkie proporcje i mieć

wyrażając się o flamandzkim autorze. „De Ghelderode i Flamandowie nauczyli mnie, jak odzyskać moją joie de vivre, jak stać się zdrową istotą ludzką", podkreślał w jednym $\mathrm{z}$ wywiadów; zob. P. Lieberman, Polish relish, „The Bulletin” 1.03.2001, s. 29. Wszystkie przekłady cytatów ze źródeł obcojęzycznych w niniejszym tekście są mojego autorstwa - T.C.

${ }^{4}$ Warto na marginesie przypomnieć, iż owo rozszczepienie dotyczyło nie tylko położenia geograficzno-politycznego, lecz także czysto artystycznej sytuacji pisarza. Autor Matugi z powodzeniem próbował się bowiem we wszystkich trzech rodzajach literackich. Debiutował jako poeta, co w pierwszych powojennych latach zaowocowało wydaniem kilku tomików wierszy; następnie zasmakował w prozie i dramacie, pisząc imponującą liczbę utworów. W swojej ponadsiedemdziesięcioletniej karierze pisarskiej Pankowski wydał w sumie 18 sztuk teatralnych, po trzy zbiory poetyckie w Polsce i Brukseli, a także 20 tomów prozatorskich w kraju oraz 10 za granicą, nie licząc przekładów na obce języki oraz utworów rozproszonych w wielu periodykach.

${ }^{5}$ P. Lieberman, op. cit., s. 28.

${ }^{6}$ A. Bertrand [wywiad z Marianem Pankowskim], „Temps Livres” grudzień 1990, s. 7.

${ }^{7}$ M. Pankowski, Matuga idzie. Przygody, Lublin 1983, s. 8.

8 W. Gombrowicz, Dzieła, t. 7. Dziennik 1953-1956, Kraków 1986, s. 194. 
na uwadze różne pozycje tych pisarzy w rankingu literackim — przechodzą przez podobny etap pisania na obczyźnie i związanych z tym rozterek identyfikacyjnych. Jeden w Belgii, drugi w Argentynie — każdy pozostaje na styku dwóch literatur ówcześnie peryferyjnych; literatur, które będąc w dużej mierze zjawiskami nieprzekładalnymi, a też „niższymi”, tylko szczątkowo uzupełniały kanon literacki ${ }^{9}$. Obaj też pozostają poza klasycznym wyborem imigranta, czyli poza opcją „bunt lub asymilacja”, wybierając trzecią drogę - mianowicie budując swoją tożsamość na opozycjach, „odmawiając wszelkiego samookreślenia” ${ }^{10}$, nie akceptując przynależności, lecz wręcz przeciwnie — na tym właśnie konstruując swoją tożsamość: tożsamość metysażu albo inaczej, jak mawiał Pankowski, „mieszańca”, „bękarta”"11.

W owej „nieczystości” narodowej, językowej, religijnej, a także, w konsekwencji, we wspomnianym wcześniej zamazaniu granic uprawianych gatunków i rodzajów literackich tkwi właśnie sedno tożsamości autora Rudolfa. Pogranicze Pankowskiego ma więc kilka wymiarów: lingwistyczny, kulturowy, antropologiczny, a wreszcie genologiczny. Można oczywiście wskazać na źródło owego pomieszania - tkwi ono w biografii pisarza, ma swoje geograficzno-topograficzne odniesienia. Wyniesioną z młodych lat aurę heterogeniczności kulturowej pogranicza karpackiego, rodzinnego Sanoka, regionu kilku języków i religii — zatem obszaru „nieczystego" - zakonserwuje Pankowski we wspomnieniach i przetworzy literacko w językowo-onomastyczno-topograficzny idiom. Dzięki temu też odnajdzie się znakomicie w Belgii, kraju dwóch narodów i języków, właśnie ze względu na jej dwoistość społeczno-kulturową. Czasem wprost wskazuje na uderzające podobieństwo swoich dwóch „małych ojczyzn” i na wynikające stąd konsekwencje: „Tam [w przedwojennym Sanoku — przyp. T.C.] spotykali się Polacy, Żydzi, Ukraińcy. [...] To dało mi łatwość i przyjemność zawierania znajomości z człowiekiem innym. Łatwiej mi więc było tam, w Brukseli, wśród Flamandów i Walonów"12.

${ }^{9}$ O sytuacji Gombrowicza w Argentynie i jego recepcji w perspektywie historii tamtejszej literatury zob. E. Kobyłecka-Piwońska, Spojrzenia z zewnatrz. Witold Gombrowicz w literaturze argentyńskiej (1970-2014), Łódź-Kraków 2017.

10 Ibidem, s. 126.

${ }^{11}$ W jednym z wywiadów Pankowski pisał: „Krajem mojego dzieciństwa są Karpaty Wschodnie — region, w którym stykają się Polska i Ukraina. [...] to bez wątpienia takie właśnie korzenie sprawiają, że staję się bardziej uczulony na problem pięknych, pobocznych obszarów — tam, gdzie zetknięcie się grup etnicznych prowadzi do powstania społeczności mieszanych, nieczystych"; zob. J. de Decker, Je me sens bien dans mon écriture, „Le Soir” 21.05.1997, s. 12. Notabene pojęcie batârdise ('bękarctwo', 'rasowa nieczystość') było z powodzeniem używane w Belgii jako pozytywny synonim terminu „metysaż”. Na ten temat zob. R. Bizek-Tatara et al., Belgiem być. Fikcja i tożsamość we francuskojęzycznej literaturze Belgii (od końca XIX do poczatku XXI wieku), Kraków 2017.

12 F. Piątkowski, Marian Pankowski, czyli szlakiem ładu, rzeka żywiołu, „Trybuna Ludu” 3-4.03.1984, s. 4. 
Nie tylko paralelność obu sytuacji „pogranicznych” jest aż nadto widoczna; podobnie widoczne jest powstrzymywanie się pisarza od jednoznacznego opowiedzenia się za którąś ze stron. Bycie „pomiędzy” — oto credo życiowo-artystyczne autora Smagłej swobody. Pankowski, który wybrał usytuowanie się „poza”, wyznawał w wywiadzie: „Zazdrośnie strzegę mojej niezależności, mojej samotności. Nie chcę być do kogokolwiek podobny"13. Doceniał to de Ghelderode, który kolejne książki Pankowskiego określał mianem „dzieł wolnego człowieka”14. Notabene określenie o „wolnym człowieku” świetnie ilustruje także kwestię tożsamości pisarza w odniesieniu do spraw polskich. Nie będąc pisarzem „krajowym”, Pankowski nie chce być bowiem twórcą , emigracyjnym” — zwłaszcza że to pojęcie wydaje się mu raczej polityczne niż społeczno-kulturowe ${ }^{15}$. Powie więc: „Nie należę do literatury emigracyjnej. Jestem Polakiem piszącym za granicą"16. Albo jeszcze bardziej obrazowo: „Ja, pisarz europejski o polskich korzeniach, który rozkwita, oddychając belgijskim powietrzem [...]”17. W antynomii „tu-tam” autor Matugi nie skłania się wyraźnie ku żadnej ze stron, pozostaje konsekwentnie dwuznaczny. Jego tożsamość tkwi właśnie w tej ciągłej kontrastowości, gdyż — paradoksalnie — „zmienność” jest „,czymś zasadniczym i trwałym”, jak twierdził narrator jednego $\mathrm{z}$ jego opowiadan ${ }^{18}$.

Belgijska krytyka literacka i tamtejsi literaturoznawcy wielokrotnie wskazywali na tę właśnie fundamentalną dwoistość, a nawet „nieczystość” biograficzno-artystycznej tożsamości Pankowskiego i jego manifestowaną postawę „marginesowca”. „Nie lubi ani podążać udeptanymi ścieżkami, ani przyjmować ustalonych idei" ${ }^{\prime \prime}$, pisała pewna krytyczka, a inny dziennikarz zatytułował swoją recenzję tymi słowy: Wolny strzelec Pankowski $i^{20}$. Krytycy podkreślali zwłaszcza upodobanie pisarza do trwania „pomiędzy”, do nieopowiadania się za jednym

${ }^{13}$ P. Haubruge, Ces écrivains belges d'ailleurs [fotokopia artykułu, b.d.].

${ }^{14}$ Cyt. za: S. Kocik, Marian Pankowski et l'exil, „Le Monde” 10.05.1969, s. 7.

${ }^{15} \mathrm{~W}$ jednym z wywiadów dla prasy polskiej głosił: ,ja już mówiłem, że emigracja mnie nie dotyczy. Że jestem Polakiem przebywającym na obczyźnie”. Zob. F. Piątkowski, op. cit., s. 4. Parę lat później, w wywiadzie dla innego periodyku krajowego, powtarzał w podobnym stylu: „nie mam świadomości pisarza emigracyjnego. Bo to nie chodzi wyłącznie o biografię, o miejsce zamieszkania. Pisarz emigracyjny jest pisarzem politycznym. Jeżeli nie pisze politycznie, nie jest pisarzem emigracyjnym, tylko żyjącym na obczyźnie. Sprawa komplikuje się, ponieważ ja jestem pisarzem pracującym na obczyźnie, a jednak zaangażowanym. Nie politycznie, ale w obronie pewnych wartości tu i ówdzie pomijanych czy też niedopatrywanych. Mam na myśli moralność świecką i tolerancję [...]". Zob. Nie jestem pisarzem emigracyjnym. Z Marianem Pankowskim rozmawia Zofia Gebhard, „Kultura” 1987, nr 2, s. 1. Należy zauważyć, że ten problem nurtował w zasadzie tylko krajowych krytyków; w Belgii nie roztrząsano kwestii „emigracyjności” Pankowskiego.

16 M.L. Bernard-Verant, Un Polonais entre deux mondes, „La Libre Belgique” 29.021.03.1992, s. 13.

17 A. Bertrand, op. cit., s. 8.

18 Zob. M. Pankowski, Zwin, [w:] idem, Złoto żałobne, Koszalin 2002, s. 60.

${ }^{19}$ M.L. Bernard-Verant, op. cit., s. 13.

${ }^{20}$ F. Lephar, Pankowski, le franc-tireur, „L'Express” 25-31.08.1989, s. 33. 
konkretnym miejscem jako życiowym gniazdem. Widać to już w samych tytułach prasowych, którymi opatrywano w Belgii wywiady z Pankowskim, eseje na jego temat lub recenzje książek. Wybór kilku tylko przykładów świetnie ilustruje tę dychotomię: Polak rozpięty pomiędzy dwoma światami ${ }^{21}$; Pankowski, Polak z Brukseli ${ }^{22}$; Polskość Belgia podszyta ${ }^{23}$; Dwaj pisarze z Polski i skadinad ${ }^{24}$; $C i$ belgijscy pisarze skądinad ${ }^{25}$.

Również w samej treści belgijskich tekstów dziennikarskich i krytycznoliterackich poświęcanych Pankowskiemu raz po raz powraca wątek kulturowego „rozpięcia”. Bodaj najwyrazistsze, najbardziej znamienne było określenie brukselskiej krytyczki: „Pankowski jest jednocześnie »stąd« i »stamtąd«”26. Co ciekawe, w recepcji belgijskiej owo „tam” nie staje się zbiorem niezrozumiałych, egzotycznych ornamentów. Przeciwnie - według zachodnich krytyków ,świat wyobraźni — zarówno w wydaniu polskim, jak i belgijskim — wsparty jest na tych samych fundamentach" ${ }^{27}$. Dlatego też spotkanie „obcy-autochton” w literaturze Pankowskiego nie kończy się agresją czy chociażby wrogością; brukselscy czytelnicy z zaciekawieniem obserwują oryginalne łączenie w literaturze odległych biegunów: „Lubieżnik Pankowski miesza z premedytacją lasek la Cambre i rezerwat Zwin z barszczem lub karpiem po polsku" 28 . W rezultacie dochodzi do pozytywnego zaskoczenia belgijskiego czytelnika: „W Polsce, czyli nigdzie? Nie: w Polsce - czyli wszędzie"29.

A jednak, mimo że Pankowski odrzuca standardową alternatywę bycia „stąd” lub „stamtąd”, jest taka kategoria, która nie tyko pomaga mu utrzymywać się ponad wszelkimi podziałami, lecz także potrafi zarazem pogodzić w sobie wszystkie sprzeczności. Więcej nawet - staje się ona dla pisarza identyfikacyjnym papierkiem lakmusowym. Jest nią mowa, a właściwie „Mowa” — bo tak zwykle, od dużej litery, zapisywał ją Pankowski.

Tenże w swojej karierze artystycznej dość szybko przeszedł od tradycyjnej kategorii ,języka” właśnie do „Mowy”. Po latach wspominał ów moment: „Po raz pierwszy użyłem świadomie słowa »Mowa« w moim wstępie do Matugi. Tym

${ }^{21}$ M.L. Bernard-Verant, op. cit., s. 13.

22 A.M. Pirard, Pankowski, Polonais de Bruxelles, „La Cité” 1991, nr 28, s. 17.

23 J. de Decker, Une polonité belgicaine, „Le Soir” 27.09.1995, s. 8.

${ }^{24}$ E. Destrée-Van Wilder, Deux écrivains de Pologne et d'ailleurs, „Le bulletin trimestriel du Cercle Culturel Polonais" październik-grudzień 1989, s. 2.

${ }^{25}$ P. Haubruge, op. cit. Warto przy okazji zwrócić uwagę, że Belgom w tych tytułowych określeniach opartych na polsko-belgijskiej opozycji wtórują polscy znawcy twórczości Pankowskiego; na przykład Krystyna Latawiec jeden ze swoich artykułów literaturoznawczych zatytułowała: $M a-$ rian Pankowski - między Karpatami a europejska Civitas, „Konspekt” 2004, nr 20, s. 159-160; inny zaś jej esej nosi tytuł: Sanok i Brugia - peryferyjne miasta Mariana Pankowskiego, „Annales Universitatis Paedagogicae Cracoviensis. Studia Poetica" 3, 2015, s. 9-22.

${ }^{26}$ M.L. Bernard-Verant, op. cit., s. 13.

27 J. de Decker, Une polonité belgicaine, s. 8.

28 A.M. Pirard, Le monde saisi par la séduction, „La Cité” [fotokopia, b.d.].

${ }^{29}$ P. Maury, Les secrets de la vie, „Le Soir” 5.01.1994, s. 11. 
terminem ogarnąłem wówczas cały dyskurs wywrotowy, podziemny, nocny, tajemniczy, ludzki, plebejski” ${ }^{30}$. Ze „słowem” - polszczyzną oficjalną, konwencjonalną — zderzał zatem „Mowę”, nacechowaną stylistyką języka mówionego, będącą mieszanką stylu potocznego, gwary i żargonu, idiomu lokalnego, a nawet wulgaryzmów. Deklarował: „Ja piszę mową, a nie polszczyzną jako taką. I moje pisarstwo to mowa, żywe słowa, pokrętne, zakazane, łowione gdzie się da"31.

Jego „odkrycie”, jakkolwiek nawiązuje przecież do klasycznych podziałów lingwistów czasów de Saussure'a, jest efektem już belgijskiej rezydentury i wpływu tamtejszych artystów:

Oni nauczyli mnie rozróżniać la langue i le langage — pierwsze to język ogólny, drugie to mój prywatny język, którego używam, który jest moją własnością i moim odkryciem. W polskim słownictwie nie mamy tego rozróżnienia, więc zastąpiłem je parą nazw: ,język” $i$ „mowa”32.

Właśnie „Mowa” staje się jego tożsamościową opoką — i to do tego stopnia, że w jednym z prywatnych zapisków, trawestując rewolucyjne hasło, zanotował sobie nawet stwierdzenie: ,langage albo śmierć"33.

Wybór „Mowy” to wybór słownictwa „nieczystego”; to wielogłos wyrastający z estetyki ludowego, plebejskiego nadurodzaju językowego. Wedle Pankowskiego tylko taka forma, wywiedziona wprost z korzeni tradycji, „nadaje słowom autentyczność" 34 . W pojęciu tradycji mieści się u pisarza konwencja przekazu ustnego, skoro — jak pisze — „na początku było matczyne słowo" 35 . To z tej językowej „domowej studni” ${ }^{36}$ będzie czerpał jako pisarz przez następne dekady:

Ja zatrzymałem w swoim słowniku tysiące wyrażeń, wspomnień, od wczesnego dzieciństwa. Są to słowa odnoszące się do naszego ciała albo do uczuć, albo związane ze świadomością przekroczeń normy. I to wszystko wypływa na powierzchnię w momentach sprzyjających twórczości literackiej ${ }^{37}$.

Mowa okazuje się zatem spoiwem jego tożsamości - a zarazem jedynym elementem poetyki, który w sposób naturalny łączy „tu” i „tam”. Mowa pozostaje bowiem ,pomiędzy” nimi, a nawet więcej — „poza” nimi, zważywszy na rytualny charakter większości zachowań i wypowiedzi bohaterów Pankowskiego. Rytuał, jak wiadomo, pomaga w wyjściu poza hic et nunc; w obrzędzie dokonuje się „niszczenie” czasu, a nawet wywołanie poczucia „bezczasu”, gdy wszystko dzieje

${ }^{30}$ Polak $w$ dwuznacznych sytuacjach, s. 117.

${ }^{31}$ P. Marecki, Nam wieczna w polszczyźnie rozróba! Marian Pankowski mówi, Kraków 2011, s. 155 .

32 Ibidem.

${ }^{33}$ Spuścizna Mariana Pankowskiego, Archiwum Biblioteki Narodowej, teczka Dramaty (Teatrowanie), sygn. akc. 019407.

34 M. Pankowski, Matuga idzie, s. 105. W innym utworze nazywa to autor ,pulsującym słowem” i jedyną autentyczną mową; zob. idem, Smagła swoboda, Paryż 1955, s. 55.

${ }^{35}$ M. Pankowski, Kora i nóż, [w:] idem, W stronę miłości, Warszawa 2001, s. 138.

36 Ibidem, s. 114.

${ }^{37}$ D.J. Cirlić, O pamięci można nieskończenie. Rozmowa z Marianem Pankowskim, „Dialog” 2003, nr 12, s. 75. 
się hors-temps i hors-lieu ${ }^{38}$. W rytuale czas nie jest więc konkretną „teraźniejszości”; to czas z „kiedy indziej”, czas „spoza”, czas mitologiczny. Ten atemporalny wymiar uzasadnia Pankowskiego bycie ,pomiędzy” w sensie topograficznym i kulturowym: między Polską i Belgią, a szerzej: pomiędzy cywilizacją Wschodu i Zachodu, czyli — używając chętnie stosowanych przezeń pojęć - między „Kartoflanią” i „Śródziemnomorzem”39.

Skoro więc Pankowski ostatecznie odnalazł jednak coś „własnego” — „Mowę", sytuującą się poza wszelkimi innymi kategoriami, do czego w takim razie potrzebna mu była Belgia? Przede wszystkim dzięki doświadczeniu belgijskiemu zaczął sytuować dokonania polskiej literatury w kontekście europejskiego dziedzictwa. Widać to nie tylko w wywiadach, lecz zwłaszcza w antologii poezji polskiej, którą Pankowski przygotował własnym sumptem na potrzeby francuskojęzycznego czytelnika ${ }^{40}$. To tam, prezentując w końcowych notkach biobibliograficznych sylwetki i dorobek polskich pisarzy, autor zadbał o to, aby wkomponować narodową twórczość w panoramę kulturowego dorobku Europy ostatnich pięciu stuleci.

Aby jednak udało się pisarzowi dokonać zabiegu owego „zeuropeizowania”, musiał jednocześnie - na własny i czytelników użytek — rodzimą literaturę „odpolszczyć”. Skutecznej lekcji „odojczyźnienia” zjawisk literackich udzielił mu jego uniwersytecki mentor profesor Claude Backvis jeszcze podczas uzupełnianych studiów slawistycznych na brukselskim Université Libre. Wspominat Pankowski: „Po jakimś czasie poczułem się uwolniony od podwójnych dybów polskich: nasilonego patriotyzmu i dogmatycznej religijności. [...] Polskie teksty literackie przestały być dla mnie czymś w rodzaju liturgii odprawianej poprzez kolejne stulecia przez żarliwych patriotów"41. Dziedzictwo kultury flamandzkiej wyznaczyło zatem Pankowskiemu nowy kurs artystyczny, który pozwolił na zerwanie z polskim — według ironicznego pisarza „świętym” — obowiązkiem pisania o ojczyźnie w sposób nabożny i martyrologiczny. Pankowski potępił dychotomię właściwą postawie Polaka wychowywanego od pokoleń na stereotypach, wedle których „obywatel jest przede wszystkim człowiekiem wierzącym i patriotą”, a język ma być „wierny dziedzictwu narodowemu” i sprzyjać ustawiczne-

38 Czyli „poza czasem” i „poza miejscem”. Zob. A. Ubersfeld, Lire le théâtre III. Le dialogue de théâtre, Paris 1996, s. 134.

39 „To zderzenie dwóch kultur, właściwie Wschodu i Zachodu, jest obecne w moim światopoglądzie”, mówił w jednym z książkowych wywiadów; zob. Polak w dwuznacznych sytuacjach, s. 79. O konfrontacji genetycznie zaszczepionej słowiańskości i nabytej paneuropejskości w książkach Pankowskiego pisał już przed laty Stanisław Barć; zob. fragment jego wstępu, idem, Pątnicy z Macierzyzny, Lublin 1987, s. 10.

${ }^{40}$ M. Pankowski, Anthologie de la poésie polonaise du XVe au XXe siècle, Aalter 1961.

${ }^{41}$ M. Pankowski, Une dette de reconnaissance, [w:] Lettres ou ne pas Lettes. Mélanges de litérature de Belgique offerts à Roland Beyeu, Louvain 2001, s. 307-308. 
mu hołdowi pamięci — „tej nabożnie podtrzymywanej sagi”42. Podsumowując $\mathrm{w}$ innym artykule uniwersyteckim dorobek polskiej przedwojennej poezji awangardowej, obwieści zatem z satysfakcją: „W miejsce wiersza-opowieści, wiersza-przemowy czy wiersza-modlitwy, wyśpiewywanego na tradycyjną nutę, rodzi się nowoczesny wiersz złożony ze słów, a nie z idei”43.

I znowu warto podkreślić, że w swym uwielbieniu „depatriotyzacji” literatury autor Matugi podzielał poglądy Witolda Gombrowicza, twórcy równie wrażliwego na kwestię samoidentyfikacji. Pankowski poświęcił temu pisarzowi osobny szkic, tak między innymi charakteryzując niewygodną sytuację autora Ferdydurke na obczyźnie: „chce uwolnić się spod jarzma polskości [...], nie może całkowicie oderwać się od problemów polskiej literatury narodowej; nie może także abstrahować od swojej przynależności do tejże literatury"44. Kolejny passus tego samego tekstu wręcz idealnie ilustruje sytuację, w jakiej znalazł się on sam — Marian Pankowski, pisarz tworzący poza kręgiem twórców zarówno emigracyjnych, jak i krajowych: „Nie odnajduje się ani pośród patetycznych i sentymentalnych pisarzy na obczyźnie, ani pośród twórców dopasowujących swoją sztukę do wymogów politycznych, wykuwających oręż, który ma posłużyć do nauczania mas"45.

Tylko taki właśnie Pankowski — „marginesowiec” z powołania i z wyboru, wieczny buntownik — był w stanie wyjść poza kanony i oficjalne wzorce tematyczne literatury narodowej, skutecznie obalać stereotypy narracji historycznej ustanowione przez oficjalną polską — i krajową, i emigracyjną — politykę „,Wielkiego Przemilczenia"46. Tylko on mógł sobie pozwolić na tak mocną, ale przecież popartą własnym doświadczeniem wypowiedź: „Wcześniej [...] nie śmiałem pisać o Auschwitz, bo zapamiętałem co innego - erotykę, okrucieństwo i miłosierdzie, ale żadnego patriotyzmu" ${ }^{\prime 7}$. I tylko z takiej postawy mogły się zrodzić utwory literackie, które do dziś burzą święty spokój odbiorców polskiej kultury narodowej ${ }^{48}$.

${ }^{42}$ M. Pankowski, La littérature et les arts, mémoire d'une nation, „Journée des slavisants 1980-1981” 1982, s. 53.

${ }^{43}$ M. Pankowski, Dix ans de la poésie polonaise (1945-1955). Une tentative de littérature dirigée, „Annuaire de l'Institut de Philologie et d'Histoire orientales et slaves” 14, 1957, s. 362.

${ }^{44}$ M. Pankowski, ,Trans-Atlantique” de Witold Gombrowicz. Une victoire de la rhétorique, „Annuaire de l'Institut de Philologie et d'Histoire orientales et slaves” 21, 1977, s. 57.

45 Ibidem.

46 Określenie jednego z polskich literaturoznawców; zob. A. Fiut, Białe rękawiczki i herbata z cytryna, [w:] idem, Pytanie o tożsamość, Kraków 1995, s. 68.

47 „Żegnaj, Maniuś, żegnaj!”. Z Marianem Pankowskim rozmawia Katarzyna Bielas, „Duży Format” nr 17 [dod. do „Gazety Wyborczej” 2006, nr 96], s. 2.

48 Mowa zwłaszcza o jego tekstach dokonujących rewizji relacji niemiecko-polskich przez przeciwstawienie oficjalnej narracji historycznej poświęconej drugiej wojnie światowej — historii osobistych, łączących wątek martyrologiczny z erotycznym: chodzi przede wszystkim o powieść Rudolf, opowiadanie Moja SS-Rottenführer Johanna oraz dramat Teatrowanie nad świętym barszczem. 


\section{Bibliografia}

Bernard-Verant M.L., Un Polonais entre deux mondes, „La Libre Belgique” 29.02-1.03.1992.

Bertrand A. [wywiad z Marianem Pankowskim], „Temps Livres” grudzień 1990.

Bizek-Tatara R. et al., Belgiem być. Fikcja i tożsamość we francuskojęzycznej literaturze Belgii (od końca XIX do początku XXI wieku), Kraków 2017.

Cirlić D.J., O pamięci można nieskończenie. Rozmowa z Marianem Pankowskim, „Dialog” 2003, nr 12.

Decker J. de, Je me sens bien dans mon écriture, „Le Soir” 21.05.1997.

Decker J. de, Une polonité belgicaine, „Le Soir” 27.09.1995.

Destrée-Van Wilder E., Deux écrivains de Pologne et d'ailleurs, „Le bulletin trimestriel du Cercle Culturel Polonais" październik-grudzień 1989.

Fiut A., Białe rękawiczki i herbata z cytryna, [w:] idem, Pytanie o tożsamość, Kraków 1995.

Gombrowicz W., Dzieła, t. 7. Dziennik 1953-1956, Kraków 1986.

Haubruge P., Ces écrivains belges d'ailleurs [fotokopia artykułu, b.d.].

Kobyłecka-Piwońska E., Spojrzenia z zewnątrz. Witold Gombrowicz w literaturze argentyńskiej (1970-2014), Łódź-Kraków 2017.

Kocik S., Marian Pankowski et l'exil, „Le Monde” 10.05.1969.

Latawiec K., Marian Pankowski - między Karpatami a europejska Civitas, „Konspekt” 2004, nr 20.

Latawiec K., Sanok i Brugia - peryferyjne miasta Mariana Pankowskiego, „Annales Universitatis Paedagogicae Cracoviensis. Studia Poetica" 3, 2015.

Lephar F., Pankowski, le franc-tireur, „L'Express” 25-31.08.1989.

Lieberman P., Polish relish, „The Bulletin” 1.03.2001.

Marecki P., Nam wieczna w polszczyźnie rozróba! Marian Pankowski mówi, Kraków 2011.

Maury P., Les secrets de la vie, „Le Soir” 5.01.1994.

Nie jestem pisarzem emigracyjnym. Z Marianem Pankowskim rozmawia Zofia Gebhard, „Kultura” $1987, \mathrm{nr} 2$.

Pankowski M., Anthologie de la poésie polonaise du XVe au XXe siècle, Aalter 1961.

Pankowski M., Dix ans de la poésie polonaise (1945-1955). Une tentative de littérature dirigée, „Annuaire de l'Institut de Philologie et d'Histoire orientales et slaves” 14, 1957.

Pankowski M., Kora i nóż, [w:] idem, W stronę miłości, Warszawa 2001.

Pankowski M., La littérature et les arts, mémoire d'une nation, „Journée des slavisants 1980-1981”, 1982.

Pankowski M., Matuga idzie. Przygody, Lublin 1983.

Pankowski M., Michel de Ghelderode, „Kultura” 1956, nr 11.

Pankowski M., Pątnicy z Macierzyzny, Lublin 1987.

Pankowski M., Smagła swoboda, Paryż 1955.

Pankowski M., ,,Trans-Atlantique” de Witold Gombrowicz. Une victoire de la rhétorique, „Annuaire de l'Institut de Philologie et d'Histoire orientales et slaves" 21, 1977.

Pankowski M., Une dette de reconnaissance, [w:] Lettres ou ne pas Lettes. Mélanges de litérature de Belgique offerts à Roland Beyeu, Louvain 2001.

Pankowski M., Zwin, [w:] idem, Złoto żałobne, Koszalin 2002.

Piątkowski F., Marian Pankowski, czyli szlakiem ładu, rzeka żywiołu, „Trybuna Ludu” 3-4.03.1984.

Pirard A.M., Le monde saisi par la séduction, „La Cité” [fotokopia, b.d.].

Pirard A.M., Pankowski, Polonais de Bruxelles, „La Cité” 1991, nr 28.

Polak w dwuznacznych sytuacjach. Z Marianem Pankowskim rozmawia Krystyna Ruta-Rutkowska, Warszawa 2000.

Ubersfeld A., Lire le théâtre III. Le dialogue de théâtre, Paris 1996.

„Żegnaj, Maniuś, żegnaj!”. Z Marianem Pankowskim rozmawia Katarzyna Bielas, „Duży Format” nr 17 [dod. „Gazety Wyborczej” 2006, nr 96]. 


\title{
A writer "from here," "from there" and "in-between." Marian Pankowski's adventures with national culture
}

\begin{abstract}
Summary
The article concerns Marian Pankowski, a special case in the history of 20th-century Polish literature. His uniqueness was due to the fact that the writer published books both in Poland and during his emigration, which he chose, but which he did not belong to. This was the reason why he stopped collaborating with the Polish centres in Paris and London. Pankowski settled down in Brussels and became an "artist apart," suspended between the exile and the homeland. This allowed him to maintain a healthy distance to important national themes, to challenge Polish stereotypes and use provocative language.
\end{abstract}

Keywords: Marian Pankowski, Polish stereotypes, emigration, artist apart, national themes 